\title{
MODEL DAN PELUANG TERJADINYA HUJAN BERDASARKAN KELEMBABAN MENGGUNAKAN REGRESI LOGISTIK BINER DI KABUPATEN MANOKWARI
}

\author{
MODEL AND PROBABILITY OF RAIN EVENT BASED ON HUMIDITY \\ USING BINARY LOGISTIC REGRESSION IN MANOKWARI REGRENCY \\ Inayatul Farach Ardianty ${ }^{1)}$, Indah Ratih Anggriyani ${ }^{2)}$ \\ 1)2) Jurusan Matematika dan Statistika, Fakultas MIPA, Universitas Papua \\ 1)ardiantyinayatulfarach@gmail.com ${ }^{2)}$ i.anggriyani@unipa.ac.id
}

Co-Author: Indah Ratih Anggriyani

\begin{abstract}
Manokwari Regrency has a tropical climate. This results in significant rainfall. One factor that stimulates rain is humidity. By using binary logistic regression, the model an chance of rainfall based on humidity can be determined. Logistic regression analysis is used to determine the relationship between categorical scale response variables and numeric or categoric scale explanatory variables. If response variable used is nominal scale with two possoble value (0 and 1), then it is called binary logistic regression. Estimation of the model is done by logit transformation. The model produce in this study is $g(x)=-23.443+0.289$ humidity. The accuracy of the model is 70.4 percent and the probability of rain for humidity lowering one unit will be reduced to 0.74 .
\end{abstract}

Keywoard: Biner Regression Logistic, Odds Ratio, Humidity, Rain

\section{PENDAHULUAN}

Secara geografis Kabupaten Manokwari terletak diantara kepala burung Pulau Papua pada posisi di bawah garis khatulistiwa antara $0^{\circ} 15$ LS dan $134^{\circ} 45$ BT (BPS Manokwari, 2018). Manokwari merupakan salah satu kabupaten yang berada di Provinsi Papua Barat dengan iklim tropis sebagaimana wilayah lain yang berada di dekat garis khatulistiwa. Curah hujan di daerah ini cukup signifikan (BMKG Klimatologi Manokwari Selatan, 2017).

Curah hujan adalah tinggi air yang diterima di permukaan sebelum mengalami aliran permukaan, evaporasi dan peresapan kedalam tanah (Endriyanto, Ihsan F. 2011). Jumlah curah hujan diukur sebagai volume air yang jatuh di atas permukaan bidang datar dalam periode waktu tertentu, seperti harian, mingguan, bulanan, dan tahunan. Tinggi air ini umumnya dinyatakan dengan satuan millimeter. Curah hujan $1 \mathrm{~mm}$ artinya air hujan setinggi satu $\mathrm{mm}$ yang jatuh pada tempat yang datar seluas $1 \mathrm{~m}^{2}$ dengan asumsi tidak ada yang menguap, mengalir dan meresap.

Kelembaban merupakan gambaran kandungan uap air di udara. Menurut Kartasapoetra (2004), besarnya kelembaban udara merupakan faktor yang menstimulasi curah hujan. Ketika kelembaban udara tinggi, uap air di udara banyak atau bisa dikatakan udara mendekati jenuh. Semakin besar kandungan uap air di udara, potensi terbentuknya butir-butir air akibat adanya pengembunan uap air tersebut juga semakin besar. Dengan demikian potensi terbentuknya awan dan hujan akan semakin besar.

Model regresi merupakan analisis data yang menggambarkan hubungan antara peubah respon dan satu atau beberapa peubah penjelas. Pada umumnya analisis regresi digunakan untuk menganalisis data dengan peubah respon 
berupa data kuantitatif atau numerik. Akan tetapi sering ditemui kasus dengan peubah respon bersifat kualitatif atau kategori.

Analisis regresi logistik digunakan untuk melihat hubungan antara peubah respon berskala kategorik dengan peubah penjelas berskala kategorik atau numerik. Jika peubah respon yang digunakan berskala nominal dengan dua kemungkinan hasil nilai yaitu 0 dan 1 disebut regresi logistik biner (Hosmer dan Lemeshow, 2000). Model regresi logistik biner dihasilkan dengan menggunakan transformasi logit. Interpretasi regresi logistik menggunakan rasio peluang (odds ratio) atau kemungkinan. Odds ratio dari suatu kejadian diartikan sebagai peluang hasil yang muncul dibagi dengan peluang suatu kejadian tidak terjadi. Secara umum, odds ratio merupakan sekumpulan peluang yang dibagi oleh peluang lainnya. Odds ratio bagi peubah penjelas diartikan sebagai jumlah relatif dimana peluang hasil meningkat $(\mathrm{o} d d s$ ratio $>1)$ atau turun (odds ratio $<1)$ ketika nilai peubah penjelas meningkat sebesar satu unit.

Model dan peluang terjadinya hujan di Kabupaten Manokwari berdasarkan kelembaban udara belum diketahui. Dengan demikian tujuan dari penelitian ini adalah menghasilkan model regresi logistik biner dan peluang logitnya.

\section{METODE}

Data dalam penelitian ini diperoleh dari BMKG Stasiun Klimatologi Manokwari Selatan Tahun 2019. Peubah respon yang digunakan adalah status terjadinya hujan $(0=$ tidak terjadi; $1=$ terjadi) dengan peubah penjelasnya adalah kelembaban udara.

Tahapan penelitian yang dilakukan sesuai dengan tahapan pada regresi logistik biner (Hosmer dan Lemeshow, 2000) yaitu:

1. Menduga parameter

Parameter dalam model regresi logistik dilakukan dengan menggunakan metode kemungkinan maksumum. Jika antara amatan yang satu dengan yang lain diasumsikan bebas maka fungsi kemungkinan maksimum yang diperoleh adalah

$$
l(\beta)=\prod_{i=1}^{p} \pi\left(x_{i}\right)^{y_{i}}\left[1-\pi\left(x_{i}\right)\right]^{1-y_{i}}
$$

dengan

i : $1,2, . . p$

$\mathrm{y}_{\mathrm{i}}$ : pengamatan pada peubah respon ke-i

$\pi\left(x_{i}\right)$ : peluang untuk peubah penjelas ke-i

Parameter $\beta_{\mathrm{i}} \quad$ diduga dengan memaksimumkan persamaan

menggunakan pendekatan logaritma, sehingga fungsi log-likelihoodnya sebagai berikut:

$L(\beta)=\sum_{i=1}^{p}\left\{y_{i} \ln \left[\pi\left(x_{i}\right)\right]+\left(1-y_{i}\right) \ln \left[1-\pi\left(x_{i}\right)\right]\right\}$

Nilai dugaan $\beta_{\mathrm{i}}$ diperoleh dengan membuat turunan pertama $\mathrm{L}(\beta)$ terhadap $\beta_{\mathrm{i}}=0$.

2. Melakukan pengujian parameter secara keseluruhan dengan Uji-G.

Pengujian parameter model secara simultan menggunakan uji nisbah kemungkinan (likelihood ratio tests) dengan statistik uji yang digunakan yaitu:

$$
\mathrm{G}=-2 \ln \left[\frac{\mathrm{L}_{0}}{\mathrm{~L}_{\mathrm{p}}}\right]
$$

dengan $\mathrm{L}_{0}$ (likelihood tanpa peubah bebas) dan $L_{p}$ (likelihood dengan peubah bebas).

Hipotesis yang digunakan adalah

$\mathrm{H}_{0}: \beta_{1}=\beta_{2}=\ldots=\beta_{\mathrm{p}}=0$

$\mathrm{H}_{0}$ : minimal ada satu $\beta_{\mathrm{i}} \neq 0$

Statistik Uji-G akan mengikuti sebaran khi kuadrat dengan derajat bebas $\mathrm{p}$, sehingga hipotesis nol ditolak jika $G>\chi_{p(\alpha)}^{2}$.

3. Melakukan pengujian parameter secara parsial dengan Uji-Wald.

Statistik uji yang digunakan yaitu:

$$
\mathrm{W}_{\mathrm{i}}=\frac{\widehat{\beta}_{\mathrm{i}}}{\widehat{\mathrm{S}} \mathrm{E}\left(\hat{\beta}_{\mathrm{i}}\right)}
$$

dengan $\widehat{\beta}_{\mathrm{i}}$ sebagai penduga $\beta_{\mathrm{i}}$ dan $\hat{\mathrm{S} E}\left(\widehat{\beta}_{\mathrm{i}}\right)$ sebagai penduga galat baku $\beta_{\mathrm{i}}$.

Hipotesis yang digunakan adalah

$\mathrm{H}_{0}: \beta_{\mathrm{i}}=0$

$\mathrm{H}_{0}: \beta_{\mathrm{i}} \neq 0$

Statistik W akan mengikuti sebaran normal baku sehingga hipotesis nol ditolak jika $\left|\mathrm{W}_{\mathrm{i}}\right|>\mathrm{Z}_{\alpha / 2}$. Hipotesis nol juga akan ditolak jika nilai peluang kurang dari taraf signifikan yang digunakan $(p$-value $<\alpha)$. Taraf 
signifikan ( $\alpha)$ yang digunakan pada penelitian ini sebesar 0.05 .

4. Interpretasi koefisien model

Interpretasi koefisien model regresi logistik biner dilakukan dengan menggunakan nilai odds ratio yang diperoleh. odds ratio didefinisikan sebagai:

$$
\widehat{\psi}=\exp \left(\widehat{\beta}_{\mathrm{i}}\right)=\exp [\mathrm{g}(1)-\mathrm{g}(0)]
$$

Odds ratio dapat diinterpretasikan sebagai kecenderungan $Y=1$ pada $X=1$ sebesar $\psi$ kali dibandingkan pada $\mathrm{X}=0$. Odds ratio antara $\mathrm{Y}=1$ dengan $\mathrm{Y}=0$ untuk $\mathrm{X}=1$ adalah $\left[\frac{\pi(1)}{1-\pi(1)}\right]$, sedangkan untuk $\mathrm{X}=0$ adalah $\left[\frac{\pi(0)}{1-\pi(0)}\right]$. Log dari kedua odds ratio tersebut didefinisikan sebagai $g(1)$ dan $g(0)$.

Model regresi logistik dibentuk dengan nilai $\mathrm{P}(\mathrm{Y}=1 \mid \mathrm{X})$ sebagai $\pi(x)$ yang dinotasikan

$$
\pi(\mathrm{x})=\frac{\exp (\mathrm{g}(\mathrm{x}))}{1+\exp (\mathrm{g}(\mathrm{x}))}
$$

Suatu fungsi dari $\pi(\mathrm{x})$ dicari dengan menggunakan transformasi logit yaitu $\mathrm{g}(\mathrm{x})$ yang dapat dinyatakan sebagai

$\mathrm{g}(\mathrm{x})=\ln \left[\frac{\pi(\mathrm{x})}{1-\pi(\mathrm{x})}\right]=\beta_{0}+\beta_{1} \mathrm{X}_{1}+\cdots+\beta_{\mathrm{p}} \mathrm{X}_{\mathrm{p}}$

Secara umum jika sebuah peubah berskala nominal atau ordinal mempunyai $\mathrm{k}$ kemungkinan nilai, maka diperlukan k-1 peubah boneka (dummy variable). Dengan demikian model transformasi logitnya menjadi

$$
g(x)=\beta_{0}+\beta_{1} X_{1}+\ldots+\sum_{u}^{k_{j}-1} \beta_{j u} D_{j u}+\beta_{p} X_{p}
$$

dengan

$\mathrm{k}_{\mathrm{j}}-1 \quad$ : Jumlah peubah boneka

$\beta_{\mathrm{ju}} \quad$ : Koefisien peubah boneka

$\mathrm{u}: 1,2, \ldots \mathrm{k}_{\mathrm{j}}-1$

$\mathrm{D}_{\mathrm{ju}} \quad: \quad \mathrm{k}_{\mathrm{j}}-1$ peubah boneka

5. Menghitung keakuratan model

Sebelum keakuraratan model dihitung, terlebih dahulu dilakukan pengelompokan pengamatan berdasarkan nilai peluang logistik (setelah model logit terbaik diperoleh). Adapun ketentuan yang digunakan sebagai berikut (Gujarati, DN; 2004):

1. Alokasikan pengamatan ke-i yang memiliki $\mathrm{Y}=1$ ke dalam kelompok "sukses", jika $\widehat{\pi\left(x_{l}\right)} \geq 0.5$

2. Alokasikan pengamatan ke-i yang memiliki $\mathrm{Y}=1$ ke dalam kelompok "gagal", jika $\overline{\pi\left(x_{l}\right)}<0.5$

Dalam model regresi logistik biner, untuk mengukur keakuratan model digunakan pseudo $\mathrm{R}^{2}$. Salah satu pseudo $\mathrm{R}^{2}$ adalah count $\mathrm{R}^{2}$ yang didefinisikan sebagai :

count- $\mathrm{R}^{2}=\frac{\text { banyaknya } \widehat{y}_{\mathrm{i}} \text { yang tepat }}{\text { banyaknya pengamatan }(\mathrm{n})}$

Semakin besar nilai count $-R^{2}$, maka model semakin akurat (Gujarati, DN; 2004 ).

\section{HASIL DAN PEMBAHASAN}

Banyaknya peubah penjelas yang digunakan hanya satu maka jumlah parameter yang dihasilkan sebanyak dua yaitu $\beta_{0}$ dan $\beta_{1}$. Nilai parameter yang dihasilkan adalah $\beta_{0}=0.289$ dan $\beta_{1}=-23.443$.

Nilai statistik G yang dihasilkan 96.995 dengan nilai peluang ( $p$-value) sebesar 0.000. Dengan menggunakan taraf signifikan sebesar 5\% maka dapat diartikan bawah secara keseluruhan peubah penjelas yang digunakan berpengaruh terhadap peubah respon. Nilai statistik $\mathrm{W}$ yang dihasilkan untuk peubah kelembaban udara sebesar -8.148 dengan galat baku 2.877 dan nilai probabilitas ( $p$ value) sebesar 0.000. Dalam hal ini kelembaban udara berpengaruh terhadap terjadinya hujan.

Model regresi logistik biner yang dihasilkan adalah $\mathrm{g}(\mathrm{x})=-23.443+0.289$ kelembaban Interpretasi koefisien dapat dilakukan dengan menggunakan nilai odds ratio yang dihasilkan. Nilai dugaan odds ratio beserta selang kepercayaan 95\% untuk peubah kelembaban udara disajikan pada Tabel 1.

Tabel 1. Nilai Rasio Odds dan Selang Kepercayaan

\begin{tabular}{|c|c|c|c|c|}
\hline & \multirow{2}{*}{$\mathrm{B}$} & \multirow{2}{*}{$\operatorname{Exp}(\mathrm{B})$} & \multicolumn{2}{|c|}{$95.0 \%$ C.I for $\operatorname{Exp}(\mathrm{B})$} \\
\cline { 4 - 5 } & & & Lower & Upper \\
\hline Kelembaban & 0.289 & 1.335 & 1.246 & 1.431 \\
\hline Konstanta & -23.443 & & & \\
\hline
\end{tabular}


Berdasarkan Tabel 1 diketahui bahwa dugaan nilai odds ratio yang dihasilkan untuk kelembaban sebesar 1.335. Hal ini berarti bahwa dengan peningkatan kelembaban sebesar satu satuan akan menyebabkan dugaan terjadinya hujan meningkat sebesar 1.335 kali. Dalam hal ini peluang terjadinya hujan untuk kelembaban lebih rendah satu satuan akan berkurang menjadi $1 / 1.335=0.74$ kali. Pada selang kepercayaan 95\% diperoleh batas bawah sebesar 1.246 dan batas atas sebesar 1.431.

Hal ini berarti bahwa setiap peningkatan kelembaban satu satuan akan menyebabkan kemungkinan terjadinya hujan meningkat antara 1.246 sampai 1.431 kali.

Penilaian keakuratan model regresi logistik ditentukan dengan menggunakan count $R^{2}$, untuk perhitungan count $-R^{2}$ dibutuhkan tabel klasifikasi yang disajikan pada Tabel 2.

Berdasarkan Tabel 2 diketahui banyaknya prediksi pengamatan yang benar 257 dan jumlah pengamatan seluruhnya 365 , sehingga nilai count $-R^{2}$ yang dihasilkan sebesar $257 / 365=0.704$. Angka ini mengindikasikan keakuratan model regresi logistik biner yang terbentuk sebesar $70.4 \%$.

Tabel 2. Tabel Klasifikasi Pengamatan

\begin{tabular}{|c|c|c|c|c|}
\hline \multirow{2}{*}{\multicolumn{2}{|c|}{ Peubah }} & \multicolumn{3}{c|}{ Prediksi } \\
\cline { 2 - 5 } & \multicolumn{2}{|c|}{ Kejadian Hujan } & Persentase Kebenaran \\
\cline { 2 - 5 } & 0 & 1 & \\
\hline Kejadian & 0 & 109 & 58 & 65.3 \\
\cline { 2 - 5 } Hujan & 1 & 50 & 148 & 74.7 \\
\hline \multicolumn{2}{|c|}{ Persentase Keseluruhan } & & & 70.4 \\
\hline
\end{tabular}

\section{KESIMPULAN}

Model regresi logistik yang diperoleh $\widehat{\mathrm{g}(\mathrm{x})}=-23.443+0.289$ kelembaban. Odds ratio yang dihasilkan sebesar 1.335 berarti bahwa dengan peningkatan kelembaban sebesar satu satuan akan menyebabkan dugaan terjadinya hujan meningkat sebesar 1.335 kali. Dalam hal ini peluang terjadinya hujan untuk kelembaban lebih rendah satu satuan akan berkurang menjadi 0.74 kali.

\section{DAFTAR PUSTAKA}

Badan Pusat Statistik. 2018. Letak Geografis Kabupaten Manokwari 2017. Manokwari. Hal 11.
Badan Meteorologi, Klimatologi, dan Geofisika (BMKG) Klimatologi Manokwari Selatan. 2017. Gambaran Umum Kabupaten Manokwari. Manokwari

Endriyanto, Ihsan F. 2011. Teknik Pengamatan Curah Hujan di Stasiun Klimatologi Kebun Percobaan Cukurgondang Pasuruan. Surabaya. Buletin Teknik Pertanian 16(2):61-63

Gurajati, DN. 2004. Basic Econometrics, fourth edition. McGraw-Hill.

Hosmer, DW dan Lemeshow, JS. 2000. Applied Logistic Regression. Canada : John Wiley \& Sons, Inc.

Kartasapoetra AG. 2004. Klimatologi: Pengaruh Iklim terhadap Tanah dan Tanaman. Jakarta: Bumi Aksara. 